\title{
SISTEM INFORMASI PERPUSTAKAAN SMP MUHAMMADIYAH 1 PEKANBARU
}

\author{
${ }^{1}$ Rice Novita, ${ }^{2}$ Wahyunur Azhari, ${ }^{3}$ Qumfa Anzir \\ 1,2,3.Program Studi Sistem Informasi, Fakultas Sains dan Teknologi UIN Suska Riau \\ Jl. HR Soebrantas KM.18 Panam Pekanbaru - Riau \\ Email: ${ }^{1}$ rice.novita.@uin-suska.ac.id, ${ }^{2} 11653103670 @$ students.uin-suska.ac.id, \\ 3umfaanzir@students.uin-suska.ac.id
}

\begin{abstract}
ABSTRAK
Perpustakaan merupakan bagian dari sumber belajar yang harus dimiliki oleh setiap sekolah atau perguruan tinggi. Agar peserta didik dengan mudah mencari informasi dan ilmu pengetahuan melalui perpustakaan. Dengan adanya perkembangan teknologi manusia berfikir untuk dapat bekerja lebih efektif dan efisien. Salah satunya yaitu menjadikan sistem konvensional ke sistem yang terkomputerisasi. Dengan memanfaatkan fasilitas, perpustakaan dapat lebih efektif dan efisien dalam pencarian, peminjaman, dan pengembalian buku. Pada penelitian ini dirancang suatu sistem informasi berbasis web menggunakan bahasa pemrograman PHP MySQL. Dengan sistem ini, diharapkan mampu mengatasi berbagai kebutuhan dari user untuk mencari buku dan melakukan transaksi seperti peminjaman dan pengembalian serta memudahkan pembuatan laporan. Dari hasil penelitian yang telah dilaksanakan penulis mengimplementasikan hasil penelitian tersebut kedalam Rancang Bangun Sistem Informasi Perpustakaan di SMP Muhammadiyah 1 Pekanbaru.
\end{abstract}

KataKunci: Perpustakaan, PHP MySQL, Sistem Informasi, Web

\section{A. PENDAhUluan}

Perkembangan ilmu pengetahuan dan teknologi sangat pesat semakin mendorong manusia untuk mengoptimalkan serta meningkatkan ilmu pengetahuan yang dikuasainya. Bahkan menciptakan suatu teknologi baru yang lebih bermanfaat bagi pengguna teknologi tersebut,.Salah satu penunjangnya adalah sarana informasi yang benar-benar berkualitas dan akurat. Informasi tersebut biasa diperoleh lewat media cetak khususnya dalam perpustakaan yang akan banyak membantu penggunanya untuk memperoleh informasi sebanyak-banyaknya [1].

Perpustakaan bukan hanya "gudang buku" melainkan menjadi tempat penyimpanan informasi, edukasi, rekreasi. Ketiga kebutuhan ini dapat dilayankan perpustakaan yang menyesuaikan dengan kebutuhan dan minat pengguna dalam ruang lingkup daerahnya. Salah satu kriteria penilaian layanan perpustakaan yang bagus adalah dilihat dari kualitas koleksinya mencakup berbagai format bahan sesuai dengan perkembangan dan kebutuhan alternatif pengguna perpustakaan terhadap media rekam informasi. Setiap kegiatan di perpustakaan tergantung terhadap pemilihan koleksi perpustakaan [2].

Penerapan TI diperpustakaan dapat difungsikan dalam berbagai bentuk, yaitu sebagai sistem informasi manajamen perpustakaan dimana kegiatan atau pekerjaan yang dapat diintegrasikan dengan sistem informasi perpustakaan antara lain adalah pengadaan, inventarisasi, katalogisasi, sirkulasi bahan pustaka, serta pengelolaan data anggota dan statistik.[3] [4].
Sistem informasi perpustakaan sangat dimungkinkan untuk mempermudah pustakawan dalam pengolahan bahan pustaka serta mempermudah dalam melayani pemustaka. Penerapan sistem informasi berbasis web di perpustakaan dapat diterapkan diberbagai jenis perpustakaan salah satunya adalah perpustakaan sekolah.

Perpustakaan sekolah didirikan untuk memenuhi kebutuhan informasi pemustaka di lingkungan sekolah, selama ini pengelolaan dan pelayanan yang diberikan perpustakaan masih bersifat manual yang memberikan dampak bagi pengelolaan dan pelayanan terhadap pemustaka, Bisa dibayangkan apabila terdapat ratusan koleksi bahan pustaka, ratusan anggota, dan jumlah peminjaman yang banyak maka akan memerlukan waktu lama dalam proses pengelolaan bahan pustaka dan pelayanan terhadap pustaka.

Melihat adanya fenomena mengenai penerapan sistem informasi perpustakaan sekolah menengah pertama, dapat dikatakan bahwa masih banyak perpustakaan sekolah menengah pertama menggunakan sistem manual, untuk itu diperlukan sebuah perencanaan untuk menerapkan sistem informasi perpustakaan. Sehubungan dengan masalah sistem informasi perpustakaan, penulis memilih tempat perpustakaan sekolah di SMP Muhammadiyah 1 Pekanbaru sebagai tempat untuk dijadikan sebuah penelitian mengenai rancang bangun sistem informasi perpustakaan. 
Hal ini dikarenakan perpustakaan SMP Muhammadiyah 1 Pekanbaru masih menggunakan sistem layanan manual, sulitnya pemrosesan transaksi data perpustakaan masih secara manual, transaksi peminjaman dan pengembalian buku di catat pada buku besar perpustakaan, sering kali buku yang di akan dipinjam oleh siswa tidak dapat diperoleh walaupun buku itu ada di perpustakaan itu. Hal ini terjadi karena sistem pencarian tidak efesien. Dan cara pendataan buku pada catatan besar buku masuk dan Ms. Excel untuk membuat laporan buku, hal ini jelas saja memakan waktu pegawai, dengan dibuatnya sistem yang akan dibangun maka saya berharap hal tersebut tidak akan terjadi lagi, karena sistm komputerisasi akan lebih menunjang siswa/I dalam mencari buku dan membantu pegawai dalam mengolah data buku.

\section{B. LANDASAN TEORI \\ B.1 Sistem}

Definisi sistem adalah seperangkat elemen yang membentuk kumpulan atau prosedur-prosedur atau bagan-bagan pengolahan yang mencari suatu tujuan bagian atau tujuan bersama dengan mengoperasikan data dan/atau barang pada waktu rujukan tertentu untuk menghasilkan informasi dan/atau energi dan/atau barang [5]. Jadi dapat disimpulkan bahwa sistem merupakan suatu kesatuan yang teratur yang saling berinteraksi untuk mencapai tujuan tertentu.

Karakteristik Sistem Pada hakikatnya suatu sistem mempunyai karakteristik atau sifat-sifat tertentu, yaitu mempunyai komponen-komponen (component), batasan sistem (boundary), lingkungan luar sistem (environment), penghubung sistem (interface), masukan sistem (input), pengolahan sistem (process), keluaran sistem (output), dan sasaran sistem (objectives) atau tujuan sistem (goal) [5].

\section{B.2 Informasi}

Defenisi Informasi Informasi dapat didefinisikan sebagai hasil dari pengolahan data dalam suatu bentuk yang lebih berguna dan lebih berarti bagi penerimanya yang menggambarkan suatu kejadian-kejadian (event) yang nyata (fact) yang digunakan untuk pengambilan keputusan [6].

Kualitas Informasi dari suatu informasi (quality of information) tergantung dari tiga hal, yaitu informasi harus akurat (accurate), tepat pada waktunya (timeliness) dan relevan (relevance)[7].

\section{B.3 Sistem Informasi}

Defenisi Sistem Informasi Menurut Robert A. Leitch, pengertian sistem informasi adalah suatu sistem di dalam suatu organisasi yang mempertemukan kebutuhan pengolahan transaksi harian, mendukung operasi, bersifat manajerial dan kegiatan strategi dari suatu organisasi dan menyediakan pihak luar tertentu dengan laporanlaporan yang diperlukan.

Sistem informasi memiliki komponenkomponen yang terdapat didalamnya yaitu terdiri dari blok masukan, blok model, blok keluaran, blok teknologi, blok basis data, blok kendali. Adapun penjelasannya sebagai berikut [2];

1. Blok masukan, input mewakili data yang masuk ke dalam sistem informasi terdiri dari metode- metode dan media untuk menangkap data yang akan dimasukkan dapat berupa dokumen-dokumen dasar.

2. Blok model terdiri dari kombinasi prosedur, logika dan model matematik yang akan memanipulasi data input dan data yang tersimpan di basis data dengan cara yang sudah tertentu untuk menghasilkan keluaran yang diinginkan.

3. Blok keluaran adalah produk dari sistem informasi yang berkualitas dan dokumentasi yang berguna untuk semua tingkatan manajemen serta senua pemakai sistem.

4. Blok Teknologi merupakan tool-box dalam sistem informasi yang digunakan untuk menerima input, menjalankan model, menyimpan dan mengakses data, menghasilkan dan mengirimkan keluaran dan membantu pengendalian dari sistem secara keseluruhan.

5. Blok basis data merupakan kumpulan dari data yang saling berhubungan datu dengan yang lainnya, tersimpan di perangkat keras komputer dan digunakan perangkat lunak untuk memanipulasinya.

Kelima komponen tersebut harus ada bersamasama dan membentuk satu kesatuan. Jika ada satu atau lebih komponen tersebut tidak ada, maka sistem informasi tidak akan dapat menjalakankan fungsinya, yaitu pengolahan data dan tidak dapat mencapai tujuanya, yaitu menghasilkan informasi yang relevan, tepat waktu dan akurat [6].

\section{B.4 Model Perancangan Object Oriented Analist and Design (OOAD) \\ B.4.1 Unified Modeling Language (UML)}

Menurut [8], bahwa beberapa literature menyebutkan bahwa Unified Modeling Language (UML) menyediakan sembilan jenis diagram, yang lain menyebutkan delapan karena ada beberapa diagram yang digabung, misanya diagram komunikasi, diagram urutan dan diagram pewaktuan digabung menjadi diagram interaksi.

Unified Modeling Language adalah sebuah bahasa yang berdasarkan grafik/gambar untuk memvisualisasi, menspesifikasikan, membangun, 
dan pendokumentasian dari sebuah sistem pengembangan software berbasis Object Oriented Analist and Design(OOAD). UML sendiri juga memberikan standar penulisan sebuah sistem blueprint, yang meliputi konsep bisnis proses, penulisan kelas-kelas dalam bahasa program yang spesifik, skema database, dan komponen- komponen yang diperlukan dalam sistem software. UML adalah salah satu tool/model untuk merancang pengembangan software yang berbasis Object Oriented Analist and Design.

\section{B.4.2 Use Case Diagram}

Use Case mendiskripsikan sebuah interaksi antara satu atau lebih aktor dengan sistem informasi yang akan dibuat. Secara kasar, Use Case digunakan untuk mengetahui fungsi apa saja yang ada di dalam sebuah sistem informasi dan siapa saja yang berhak menggunakan fungsi- fungsi itu.

\section{B.4.3 Activity Diagram}

Activity Diagram menggambarkan aliran fungsionalitas sistem. Dapat juga digunakan untuk menggambarkan aliran kejadian (flow of events) dalam use case. Aktivitas dalam digram dipresentasikan dengan bentuk bujur sangkar bersudut tidak lancip, yang didalam nya berisi langkah-langkah apa saja yang terjadi dalam aliran kerja. Ada sebuah keadaan mulai (start state) yang menunjukkan dimulainya aliran kerja, dan sebuah keadaan selesai (end state) yang menunjukkan akhir diagram, titik keputusan dipresentasikan dengan diamond. Diagram aktivitas tidak perlu dibuat untuk setiap aliran kerja, tetapi diagram ini akan sangat berguna untuk aliran kerja yang komplek.

\section{B.4.4 Class Diagram}

Class Diagram menunjukan interaksi antara kelas dalam sistem. Kelas mengandung informasi dan tingkah laku (behavior) yang berkaitan dengan informasi tersebut. Sebuah kelas pada diagram kelas dibuat untuk setiap tipe objek pada diagram sekuensial atau diagram kolaborasi

\section{B.5 PHP}

PHP (personal home page) menurut [9], PHP/F1 merupakan nama awal dari PHP. PHP - personal home page, F1 adalah Form Interface. Dibuat pertama kali oleh Rasmus Ledoft. PHP awalnya merupakan program CGI yang dikhususkan menerima input melalui form yang ditampilkan di web browser. Software ini disebarkan dan dilisensikan sebagai perangkat lunak open source. PHP merupakan kependekan dari PHP HyperText Preprocessor, merupakan bahasa script server side yang disisipkan dalam dokumen HTML.

\section{B.6 MySQL}

MySQL adalah salah satu jenis database server yang sangat terkenal dan banyak digunakan untuk membangun aplikasi web yang menggunakan database sebagai sumber dan pengolahan datanya [10].

\section{B.7 Perpustakaan}

Banyak batasan atau pengertian perpustakaan yang disampaikan oleh para pakar dibidang perpusatakaan yang disampaikan oleh para pakar dibidang perpustakaan. Ada beberapa pengertian perpustakaan dibawah ini :

a. Perpustakaan diartikan sebuah ruangan atau gedung yang digunakan untuk menyimpan buku dan terbitan lainnya yang biasanya disimpan menurut tata susunan tertentu yang digunakan pembaca bukan untuk dijual (Sulistya Basuki, Pengantar Ilmu Perpustakaan, Universitas Terbuka,1993)

b. Dalam pengertian yang terbaru seperti yang tercantum dalam keputusan Presiden RI Nomor II disebutkan bahwa perpustakaan merupakan salah satu sarana pelestarian bahan pustaka sebagai teknologi dan kebudayaan dalam rangka mencerdaskan kehidupan bangsa dan menunjang pelaksanaan pembangunan nasional (Marto Atmojo Karmidi, Manajemen Perpustakaan Khusus, Universitas Terbuka, Jakarta, 1997).

c. Menurut RUU Perpustakaan pada Bab I pasal 1 menyatakan Perpustakaan adalah institusi yang mengumpulkan pengetahuan tercetak dan terekam, mengelolanya dengan cara khusus guna memenuhi kebutuhan intelektualitas para penggunanya melalui beragam cara interaksi pengetahuan.

Secara umum dapat disimpulkan bahwa pengertian perpustakaan adalah "suatu institusi unit kerja yang menyimpan koleksi bahan pustaka secara sistematis dan mengelolanya dengan cara khusus sebagai sumber informasi dan dapat digunakan oleh pemakainya".

\section{METODOLOGI PENELITIAN}

Pendekatan pengembangan sistem yang digunakan pada penelitian ini adalah object oriented analysis and design (OOAD). Ada tiga buah diagram unified modeling language (UML) yang digunakan, yaitu: (1) usecase diagram; (2) activity; dan (3) class diagram. 


\section{C.1 Perencanaan}

Tahap perencanaan dilakukan untuk mengidentifikasi permasalahan yang terjadi. Tahap ini dilakukan dengan cara wawancara dan observasi.Wawancara dilakukan ke Kepala Perpustakaan dan petugas perpustakaan SMP Muhammadiyah 1 Pekanbaru. Observasi dilakukan pada Perpustakaan SMP Muhammadiyah 1 Pekanbaru. Selain untuk mengindentifikasi masalah dan kebutuhan pengguna, wawancara dan observasi juga menghasilkan data primer dan data sekunder.

\section{C.2 Analisa dan Hasil}

Pada tahap ini, baik untuk rancang bangun sistem informasi perpustakaan dilakukan: (1) analisa sistem yang sedang berjalan;(2) analisa sistem usulan; dan (3) perancangan sistem. Analisa sistem yang sedang berjalan dilakukan dengan cara menganilisis hasil wawancara dan observasi serta dokumen-dokumen yang didapat dari tahap perencanaan. Sedangkan pada tahap analisa sistem usulan dibuat: (1) arsitektur sistem; (2) analisa kebutuhan fungsional sistem; dan (3) aliran data yang terdapat pada sistem.Kebutuhan fungsional dan aliran data secara berturut-turut digambarkan menggunakanusecasediagram dan activity diagram. Pada tahap perancangan sistem dilakukan pembuatan class diagram, perancangan basis data, perancangan struktur menu serta perancangan antarmuka.

\section{ANALISA DAN PERANCANGAN D.1. Analisa Sistem yang Sedang Berjalan D.1.1. Perpustkaan SMP Muhammadiyah 1 Pekanbaru}

Berdasarkan hasil pengamatan, berikut ini uraian secara umum sistem yang sedang berjalan pada proses yang ada di perpustakaan SMP Muhammadiyah 1 Pekanbaru yang mana setiap siswa yang mengunjungi perpustakaan terlebih dahulu harus mendaftarkan nama atau data anggota ke dalam buku besar yang disediakan pihak perustakaan secara manual, hal ini membuat data pengunjung tidak bisa tersimpan dengan baik karena data pengunjung bisa rusak, hilang dan tidak jelas adanya. Dalam hal pencarian buku yang dilakukan siswa atau pengunjung di perpustakaan SMP Muhammadiyah 1 Pekanbaru juga masih dilakukan secara manual sehingga pengunjung mengalami kesulitan dalam mencari buku yang akan dipinjam karena banyak nya jumlah buku yang ada diperpustakaan tersebut, sedangkan informasi buku tersebut tidak diinformasikan statusnya apakah buku tersebut masih ada atau sedang dipinjam. Sedangkan peminjaman buku dan pengembalian buku di perpustakaann SMP Muahammadiyah 1 Pekanbaru masih manual yaitu dicatat di buku besar.

\section{D.2 Analisa Sistem Usulan}

Berdasarkan sistem yang sedang berjalan pada perpustakaan SMP Muhammadiyah 1 Pekanabaru diperlukan beberapa tambahan fitur yang dapat mempermudah petugas perpustakaan dalam mengelola data pengunjung yang datang ke perpustakaan sekolah dan juga membantu pengunjung perpustakaan untuk mengetahui informasi tentang buku yang ada diperpustakaan sekolah tanpa harus mencari langsung ke rak buku yang tersedia untuk menemukan buku yang dibutuhkan. Pada sistem ini juga terdapat menu untuk memperbaharui data perpustakaan yang befungsi jika pihak yayasan ingin mengganti nama perpustakaan dan juga data perpustakaan yang lainnya. Deskripsi sistem yang diusulkan dapat dilihat dalam bentuk Use Case Diagram.

Sistem usulan ini menggunakan data base untuk menyimpan data-data buku dan jumlah data anggota perpustakaan SMP Muhammadiyah 1 Pekanbaru, selain itu sistem usulan ini juga dapat menyimpan data admin. Pada sistem ini admin dapat masuk kedalam sebuah sistem dengan melakukan login terlebih dahulu menggunakan username dan password, admin juga bisa mengelola data jumlah pengunjung yang datang keperpustakaan sekolah, admin juga dapat membantu pengunjung perpustakaan dalam memberikan informasi lokasi buku yang dibutuhkan sekaligus dapat mengelola data buku dan memperbaharui data perpustakaan. Dalam sistem yang diusulkan ini terdapat beberapa kelebihan diantaranya :

1. Memudahkan petugas perpustakaan dalam memberikan informasi lokasi buku yang dibutuhkan oleh siswa atau pengunjung yang datang keperpustakaan sekolah.

2. Memudahkan petugas perpustakaan untuk membuat laporan jumlah data siswa.

3. Memudahkan petugas perpustakaan dalam mengelola data buku.

Berdasarkan anaslisa tersebut maka dapat dilakukan sebuah rancangan sistem informasi perpustakan berbasis web pada Yayasan Pendidikan Islam Terpadu, dengan menggunakan diagram UML (Unifeld Modeling Language). Adapun UML yang digunakan adalah sebagai berikut :

1. Use Case Diagram

2. Class Diagram

3. Activity Diagram.

\section{D.2.2 Kebutuhan Fungsional Sistem}

Sistem yang dirancang memiliki dua buah aktor, yaitu petugas dan siswa. Kebutuhan fungsional sistem dapat dilihat pada usecase diagram pada 
Jurnal Ilmiah Rekayasa dan Manajemen Sistem Informasi, Vol. 5, No. 2, Agustus 2019, Hal. 191-198

e-ISSN 2502-8995, p-ISSN 2460-8181

Gambar 1. Adapun penjelasan data pada masingmasing usecase dapat dilihat pada usecase diagram.

\section{D.2.3 Perancangan Sistem}

Berdasarkan hasil perancangan, sistem yang dibangun memiliki tujuh buah class pada class diagram-nya. Detail class beserta atribut dan methodnya dapat dilihat pada Gambar 2.activity diagram bisa dilihat ditable 4.Rancangan struktur menu untuk sistem dapat dilihat pada Gambar 5.

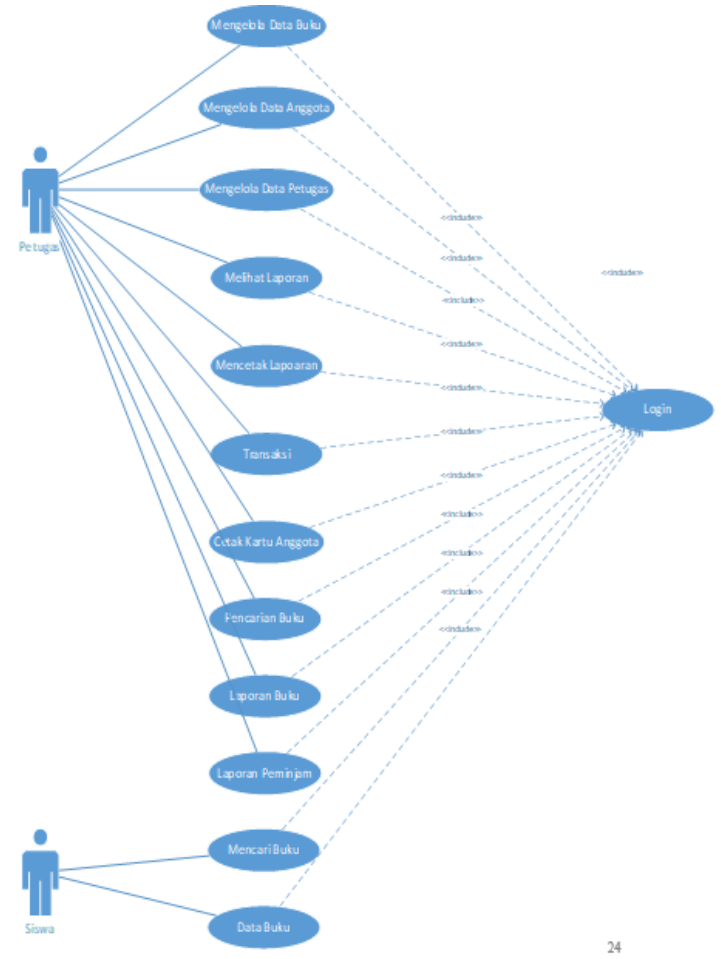

Gambar 1. Usecase diagram Sistem Informasi Perpustakaan Pada SMP Muhammadiyah 1 Pekanbaru

Pada Gambar 1. Merupakan usecase Diagram Sistem Infomasi Perpustakaan pada SMP muhammadiyah 1 Pekanbaru. Pada Usecase Diagram Menggambarkan kegiatan yang dilakukan oleh masing masing aktor. Pada sistem informasi perpustakan SMO Muhammadiyah 1 Pekanbaru terdapat duak aktor. Aktor pertama Admin, admin merupakan petugas perpustakaan yang mempunyai hak akses penuh terhadap siswa. Aktor kedua siswa sebagai anggota perpustakaan. Kegiatan yang dapat dilakukan siswa adalah pencarian buku dan peminjaman buku.

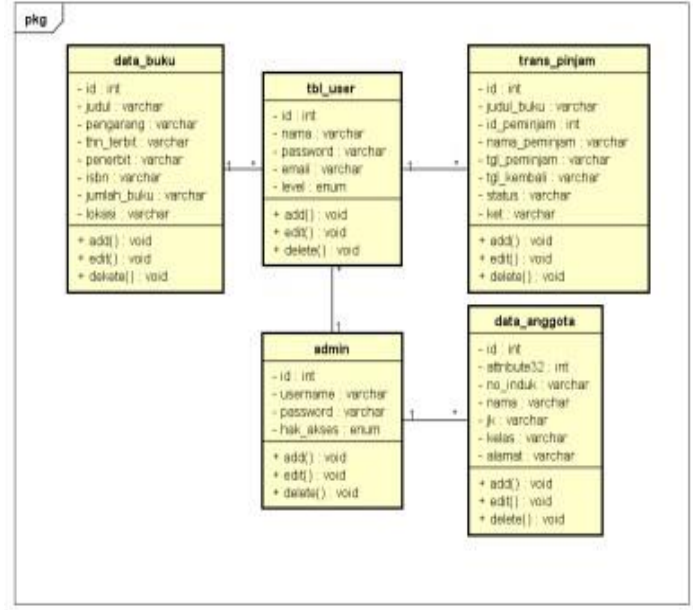

Gambar 2. Class Diagram

Pada Gambar 2 menggambarkan class yang dihasilkan pada sistem informasi perpustakaan. Terdapat lima class pada sistem infomrasi perputsakaan yang saling berelasi,diantaranya Class buku, class user, class pinjam, class anggota dan class admin.

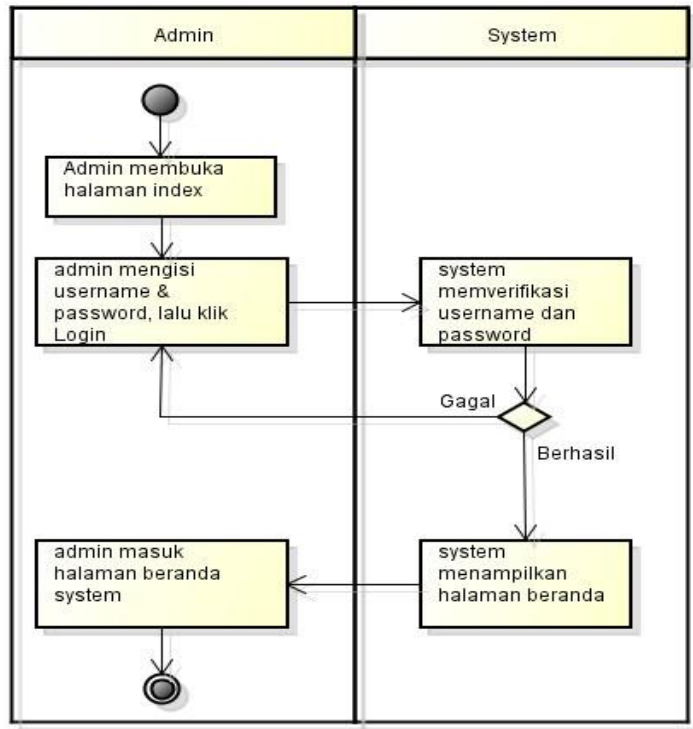

Gambar 3. Activity login admin 


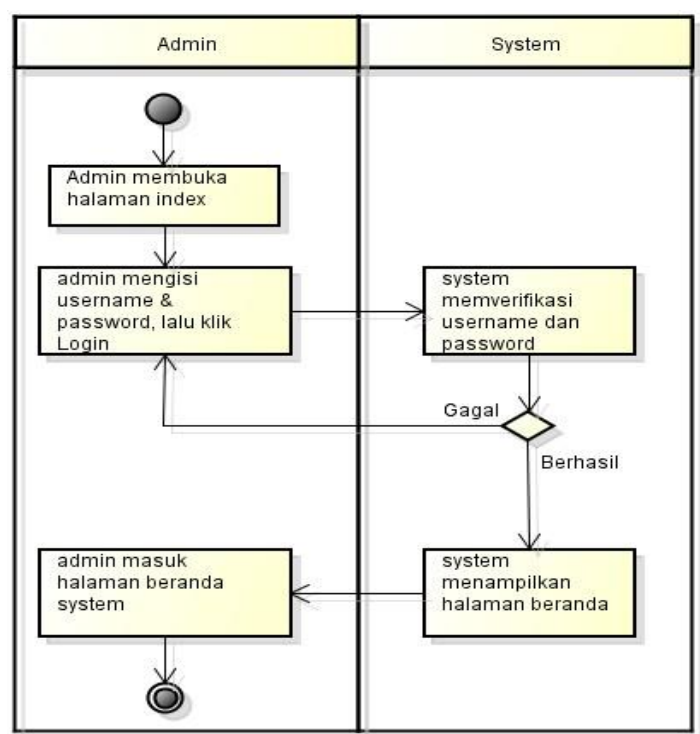

Gambar 4. Activity data buku

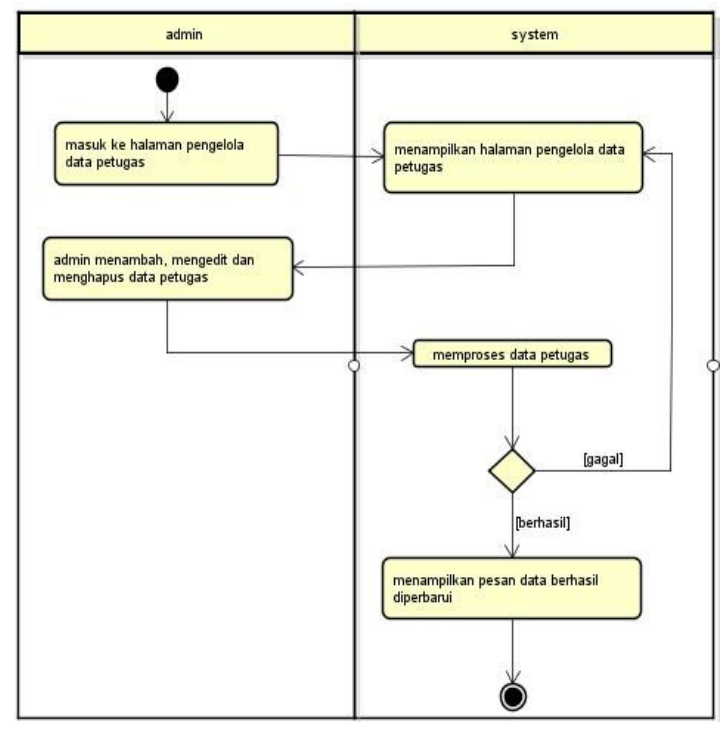

Gambar 5. Activity data anggota

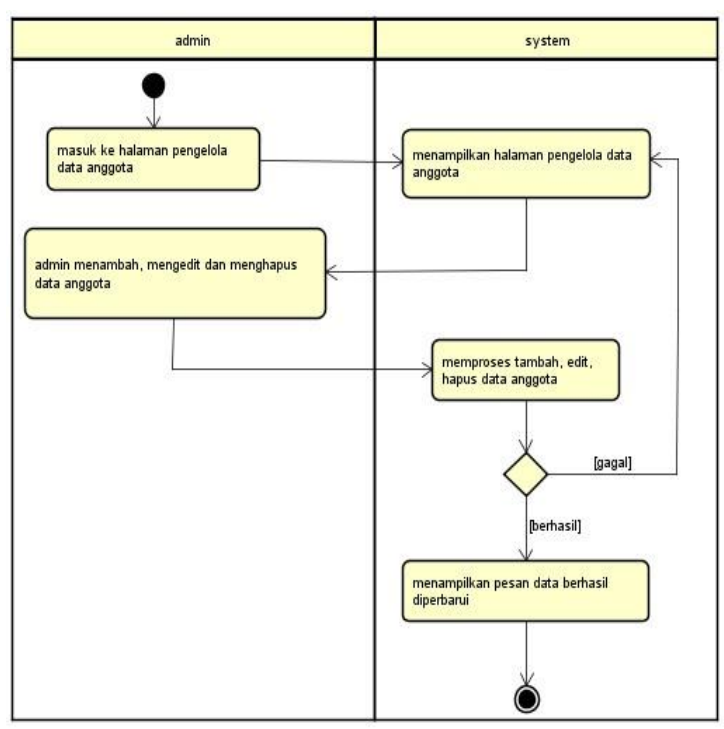

Gambar 6. Activity mengelola data anggota

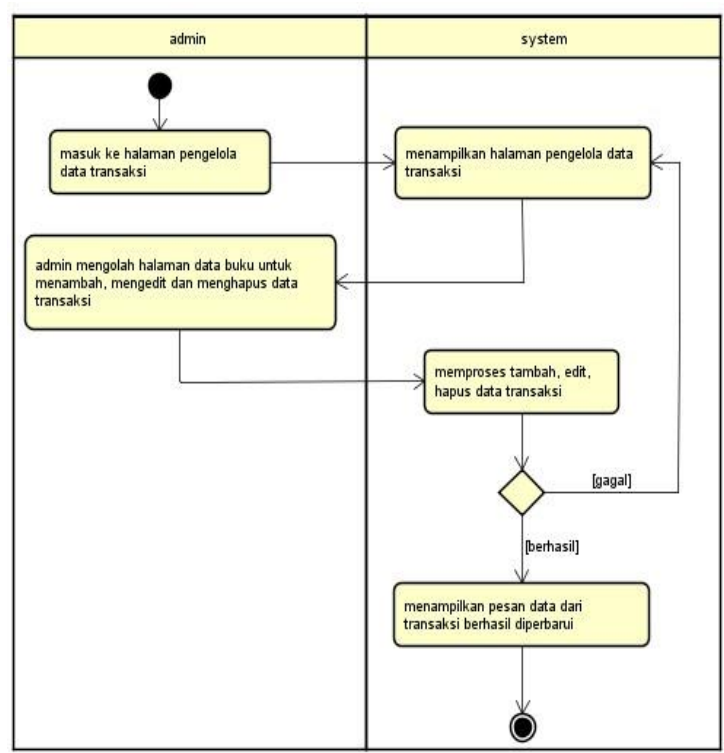

Gambar 7. Activity melihat laporan 
Jurnal Ilmiah Rekayasa dan Manajemen Sistem Informasi, Vol. 5, No. 2, Agustus 2019, Hal. 191-198

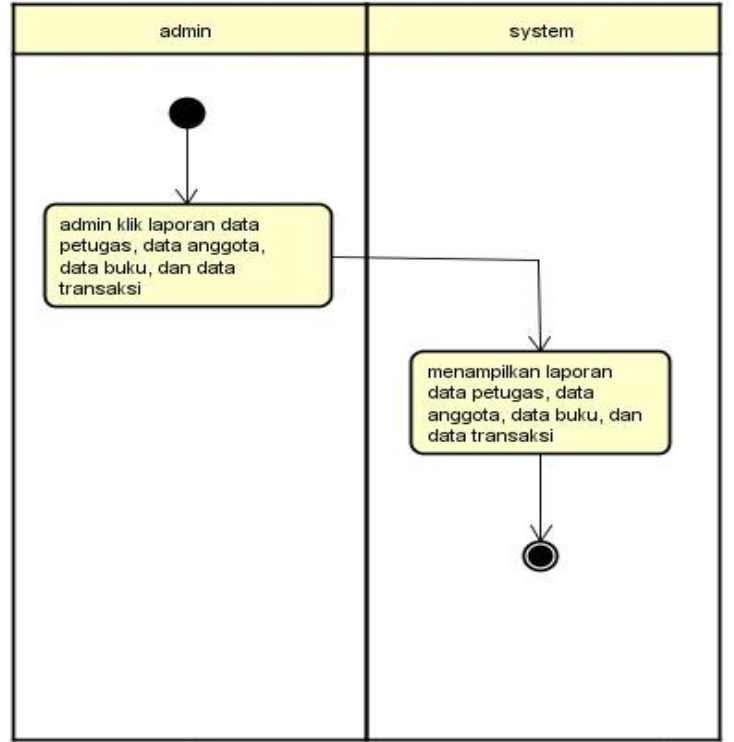

Gambar 8. Activity transaksi

\section{E. HASIL IMPLEMANTASI DAN \\ PENGUJIAN}

\section{E.1. Hasil ImplementasiSistem Informasi Perpustakaan}

Pada sistem perpustakaan terdapat 13 buah halaman antarmuka, yaitu:(1) halaman login admin; (2) beranda admin; (3) halaman data anggota (DA); (4) halaman tambah data anggota; (5) halaman data buku;(6) halaman tambah data buku;(7) halaman transaksi (NT);(8) halaman laporan;(9) halaman laporan buku;(10) halaman laporan anggota;(11) halaman user.

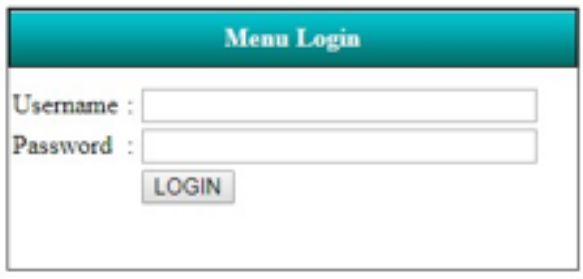

Gambar 9. Halaman Login

Gambar 9 merupakan halaman login perpustakaan. Pada halaman ini terdapat kolom username sebagai id nya dan paswoord untuk keamanannya, sementara tombol login untuk membuka halaman beranda sistem.

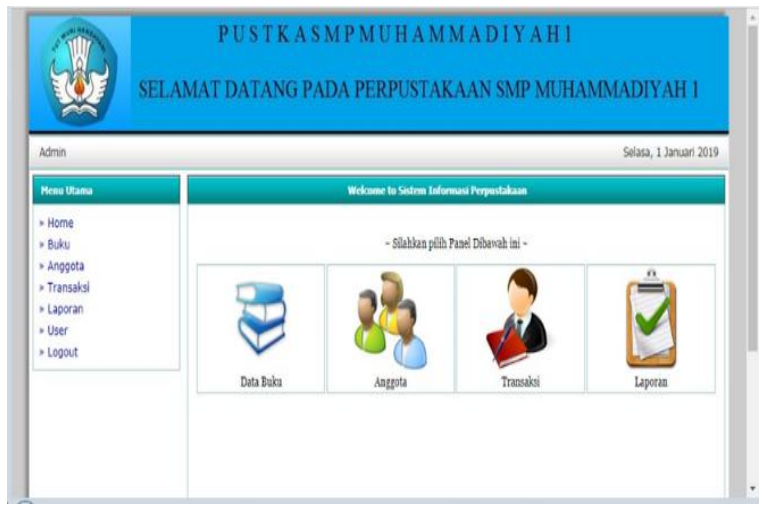

\section{Gambar 10. Beranda Admin}

Gambar 10 merupakan halaman beranda admin. Pada halaman ini terdapat tujuh buah menu, yaitu: (1) home; (2) buku; (3) anggota; (4) transaksi; (5) laporan; (6) user; (7) Logout.

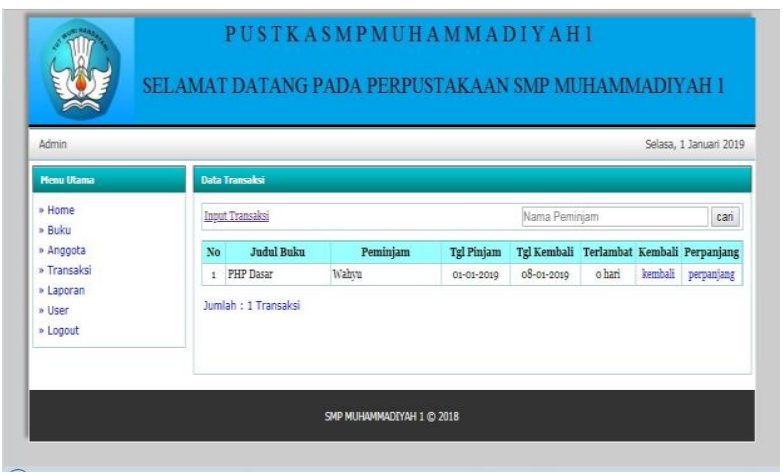

\section{Gambar 11 Halaman Transaksi}

Gambar 11 merupakan halaman transaksi. Pada halaman ini admin akan melihat datadatatransaksi yang sudah diinputkan pada tahap input data transaksi peminjaman dan pengembalian buku.

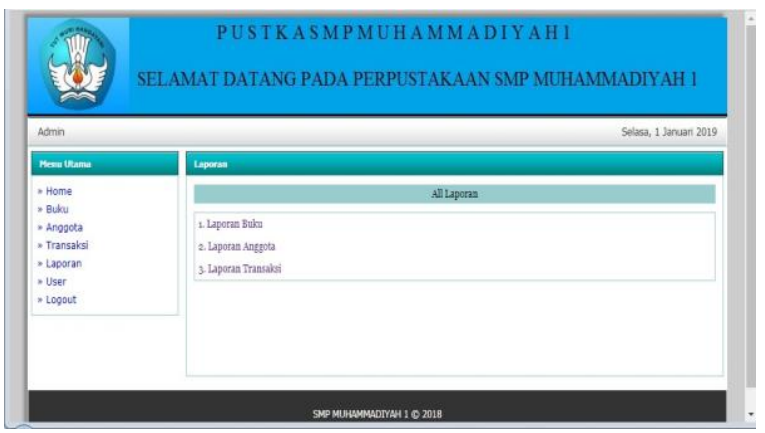

Gambar 12. Halaman Laporan

Gambar 12 merupakan gambar halaman laporan. Pada halaman ini admin bisa melihat dan mencetak laporan buku, anggogta, transaksi. 


\section{F. KESIMPULAN dan SARAN}

\section{F1. Kesimpulan}

Sistem Informasi Perpustakaan Studi Kasus SMP Muhammdiyah 1 Pekanbaru, maka dapat diambil kesimpulan sebagai berikut :

1. Dengan adanya sistem ini dapat membantu petugas pustaka dalam mengelola data jumlah anggota dan peminjaman dan pengembalian buku yang ada di perpustakaan sekolah secara cepat.

2. Sistem yang sudah dibangun dan akan diterapkan nantinya, diharapkan bisa menjadi solusi daripermasalahan yang muncul pada pengelolaan data di perpustakaan SMP Muhammadiyah 1 Pekanbaru.

3. Kesalahan-kesalahan yang disebabkan oleh keterbatasan seperti human error ataupun ketidak sengajaan dapat dikurangi dengan menggunakan sistem komputerisasi.

\section{F2. Saran}

Setelah melakukan evaluasi terhadap sistem secara keseluruhan, diharapkan penelitian ini dapat dikembangkan lebih lanjut dengan menambah fitur fitur yang lebih lengkap.

\section{REFERENSI}

[1] Prof. Dr. Sri Mulyani. 2016. Metode Analisis dan Perancangan Sistem. Bandung: Abdi SisteMatika.

[2] Ade, Kohar. 2003. Teknik Penyusunan Kebijakan Pengembangan Koleksi Perpustakaan : Suatu Implementasi Studi Retrospektif. Jakarta

[3] Ladjamudin, Al-Bahra Bin. 2013. Analisis dan Desain Sistem Informasi. Yogyakarta: Gave Media.

[4] Muharti, R. 2004. Model Implementasi Protokol OAI dalam Indonesia DLN dan Hubungannya dengan Digital Library di Luar Negri. Jakarta

[5] Pratama. I Putu Agus Eka, 2014 Sistem Informasi dan Implementasinya, Bandung: Informatika.

[6] Taufiq, Rohmat. 2013. Sistem Informasi Manajamen. Konsep Dasar, Analisis dan Metode Pengembangan. Yogyakarta : Graha Ilmu.

[7] Tiningsih, Erlin Wahyu Timor. 2011. Sistem Informasi Pengolahan Data Perpustakaan Pada SMK Negeri 1 Demak : Program Studi Teknik Informatika Fakultas Teknik Universitas Sultan Fatah, Demak.Aplikasi Panduan
[8] Mulyani, Sri. 2016. Metode Analisis dan Perancangan Sistem. Bandung. Abdi Sistematika. ISBN : 978-979-19906-2-2.

[9] Nugroho, Bunafit, 2008. Membangun Sistem Informasi Berbasis WEB dengan PHP dan MySQL. Yogyakarta:GavaMedia.

[10] Kadir,Abdul. 2009. "Dasar perancangan \& Implementasi”, Yogyakarta: AndiOffset. 